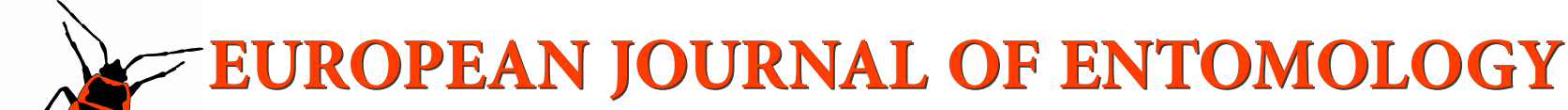 \\ ISSN (online): 1802-8829 \\ http://www.eje.cz \\ Eur. J. Entomol. 117: 481-489, 2020 \\ doi: 10.14411/eje.2020.051 \\ ORIGINAL ARTICLE
}

\section{Revision of taxonomic status of Anthrenus pimpinellae isabellinus (Coleoptera: Dermestidae)}

\author{
Graham J. HOLloWAY ${ }^{1}$, Dimitrios E. BAKALOUdiS ${ }^{2}$, Maxwell V.L. BARCLAY ${ }^{3}$, IVAN CAÑAdA LUNA ${ }^{4}$, \\ Christopher W. FOSTER ${ }^{1}$, Marcin KADEJ ${ }^{5}$, Amanda CALLAGHAN ${ }^{1}$ and Robert J. PAXTON ${ }^{6}$ \\ ${ }^{1}$ Centre for Wildlife Assessment and Conservation, School of Biological Sciences, Harborne Building, Whiteknights, University \\ of Reading, Reading RG6 6AS, UK; e-mails: g.j.holloway@reading.ac.uk, c.w.foster@reading.ac.uk, a.callaghan@reading.ac.uk \\ ${ }^{2}$ Aristotle University of Thessaloniki, School of Forestry and Natural Environment, PO Box 241, University Campus, \\ 54124 Thessaloniki, Greece; e-mail: debakaloudis@for.auth.gr \\ ${ }^{3}$ Department of Life Sciences, Natural History Museum, London SW7 5BD, UK; e-mail: m.barclay@nhm.ac.uk \\ ${ }^{4} 44$ General Riera Street, Palma, 07003 Mallorca, Spain; e-mail: ivan_cl9@hotmail.com \\ ${ }^{5}$ Department of Invertebrate Biology, Evolution and Conservation, Faculty of Biological Science, University of Wrocław, \\ Przybyszewskiego 65, PL-51-148 Wrocław, Poland; e-mail: marcin.kadej@uwr.edu.pl \\ ${ }^{6}$ Institute for Biology, Martin Luther Universität Halle-Wittenberg, Hoher Weg 8, 06100 Halle (Saale), Germany; \\ e-mail: robert.paxton@zoologie.uni-halle.de
}

Key words. Coleoptera, Dermestidae, Anthrenus dorsatus, Anthrenus pimpinellae, Anthrenus isabellinus, taxonomy, new synonymy, morphology, barcode, genitalia, antennae, sternite IX, species concept

\begin{abstract}
For 160 years, Anthrenus pimpinellae isabellinus Küster, 1848 has been considered a subspecies of $A$. pimpinellae Fabricius, 1775. However, habitus shape differs between the subspecies with $A$. $p$. isabellinus being broader than $A$. p. pimpinellae and resembling more closely $A$. dorsatus Mulsant \& Rey, 1868. Here A. p. pimpinellae and $A$. p. isabellinus, are examined to look for evidence that they comprise a single taxonomic unit. Habitus and genital structures are considered, and the universal animal barcode region of the mitochondrial cytochrome oxidase I gene is sequenced. The results of the morphological, morphometric, and genetic analyses mirror each other perfectly and suggest that $A$. $p$. isabellinus is the same species as $A$. dorsatus rather than being a subspecies of $A$. pimpinellae. The very small intraspecific DNA sequence variation supports the view that $A$. dorsatus and $A$. $p$. isabellinus belong to a single species that diverges considerably from $A$. p. pimpinellae. Morphology, including genital structure, is congruent with the genetic data and provides a powerful way of resolving species organisation in these widespread beetles. In view of these findings, Anthrenus isabellinus Küster, 1848 is restored to full species status and Anthrenus dorsatus Mulsant \& Rey, 1868 becomes its new junior subjective synonym.
\end{abstract}

ZooBank Article Registration: http://zoobank.org/urn:Isid:zoobank.org:pub:4519E16A-7440-4646-BAB3-4FEF90949730

\section{INTRODUCTION}

The Dermestidae is a moderately large family of beetles with the number of species currently claimed to lie between 1600 and 1700 (Háva, 2015, 2020), but the taxonomy of parts of the family is poorly understood. Anthrenus is a relatively large genus within the Dermestidae numbering about 260 species (Háva, 2020). Anthrenus provides an example of complex, unresolved, taxonomy and is split into 10 subgenera. Kadej (2018) carried out an examination of the genus Anthrenus using larval characteristics and concluded that only the species within the subgenus $\mathrm{An}$ threnus were monophyletic, all other subgenera forming a polyphyletic assemblage.

Even though the subgenus Anthrenus appears to be monophyletic, it is not without its difficulties. Notably, it contains many phenotypically similar species within the A. pimpinellae species complex. All its species carry a mixture of black, orange (yellow or brown) and white (or off-white) scales, and nearly all species have most of the white scales on the dorsal surface arranged as a broad band across the elytra. Some of these species are sufficiently similar in appearance to have caused identification issues since $A$. pimpinellae Fabricius, 1775 was first described (Beal, 1998; Kadej et al., 2007).

Anthrenus pimpinellae is currently split into two wellknown subspecies based on coloration: $A$. p. pimpinellae and $A$. p. isabellinus Küster, 1848. Küster (1848) originally described $A$. isabellinus as a separate species but it was quickly relegated to a subspecies of $A$. pimpinellae by Schaum (1862). It is not clear on what basis Schaum 
(1862) concluded that $A$. p. pimpinellae and A. p. isabellinus were conspecific. No examination of the genitalia appears to have been carried out, the colour patterns differ, and the distributions overlap. Anthrenus p. pimpinellae is claimed to have a cosmopolitan distribution (Háva, 2020), whereas A. p. isabellinus is distributed around the western Mediterranean (Háva, 2020). In other words, the subspecies are sympatric in the western Mediterranean and, according to theory (Mallet, 1995, 2008), should not be able to retain integrity.

In previous studies, A. dorsatus Mulsant \& Rey, 1868, another species in the $A$. pimpinellae complex, has been noted both in Greece (Holloway \& Bakaloudis, 2019) and in USA (Holloway et al., in press). In both locations, $A$. p. isabellinus was found alongside $A$. dorsatus on flowers of Hemlock, Conium maculatum L. (Apiaceae). Both $A$. $p$. isabellinus and $A$. dorsatus are broad-bodied, considerably broader than A. p. pimpinellae (Holloway \& Bakaloudis, 2020). Combined, this evidence suggests that the subspecific association of $A$. p p pimpinellae and $A$. p. isabellinus needs to be questioned. A study was carried out to establish the true taxonomic relationship between $A$. p. pimpinellae, A. p. isabellinus, and A. dorsatus.

\section{MATERIALS AND METHODS}

A three-pronged approach is taken: (1) to examine the genital structure, supplemented by other features such as antennal structure, (2) to carry out a morphometric examination, and (3) to sequence a fragment of the mitochondrial COI gene (the universal animal barcode region of the mitochondrial cytochrome oxidase I gene) to establish phylogenetic relationships among the species. The nomenclature and zoogeography follow Háva (2015), and the conventional nomenclature, including of the taxa under study, is used.

\section{Study insects}

Material was collected from around Thessaloniki (Greece), Mallorca (Spain), and Maryland (the United States of America), supplemented with preserved specimens from the Natural History Museum (NHM), London. From the field, specimens were almost exclusively collected from white flowers such as Hoary Cress (Lepidium draba L., Brassicaceae) and Hemlock (C. maculatum) (see Holloway \& Bakaloudis, 2019; Holloway et al., in press). Dermestidae were knocked from the flowers into a plastic tray to facilitate aspiration using a pooter. All field collected specimens along with those from the NHM were used for the morphological analysis.

Only in Greece were A. p. pimpinellae, A. p. isabellinus and A. dorsatus found together in the field, along with Anthrenus scrophulariae albidus Brullé, 1832. In the laboratory, the Greek insects collected from Sindos, near Thessaloniki $(40.673368 \mathrm{~N}$, $22.806583 \mathrm{E}$ ) were separated by species/subspecies and retained on a mixture of dead insects, feathers, and bone and blood meal. When the adult insects died, they were removed from the breeding medium and stored in $2 \%$ acetic acid until dissection. F1 offspring of each species/subspecies were reared through to produce insects for genetic analysis. When insects emerged from their pupal cases, they were flash frozen at $-30^{\circ} \mathrm{C}$ then stored in $99 \%$ ethanol to preserve the DNA. Prior to homogenisation to extract the DNA, some specimens were quickly dissected (see morphometric analysis) under a Brunel BMSL zoom stereo LED microscope to confirm species identity.

Table 1. List of DNA sequenced Anthrenus specimens whose parents were collected at Sindos (Greece). "\% ID to nominal species" is the GenBank \% DNA sequence identity to the colour-based species identity, except in $A$. dorsatus (values asterisked) whose \% sequence ID is to Anthrenus pimpinellae (the highest GenBank sequence ID to all Anthrenus dorsatus sequences) because GenBank does not contain any Anthrenus dorsatus sequences. ND - sex not determined. Reference specimens (parents and additional F1 offspring from the same breeding vial) for sequenced individuals are located in the private collection of G.J. Holloway.

\begin{tabular}{|c|c|c|c|c|c|c|}
\hline $\begin{array}{l}\text { Label on } \\
\text { Fig. } 5\end{array}$ & $\begin{array}{l}\text { Identification based } \\
\text { on colour pattern }\end{array}$ & Sex & $\begin{array}{l}\% \text { ID to } \\
\text { nominal } \\
\text { species }\end{array}$ & $\begin{array}{l}\text { Identification based on } \\
\text { genitalia (Figs } 1-3 \text { ) and } \\
\text { morphometrics (Fig. } 4 \text { ) }\end{array}$ & $\begin{array}{l}\text { Identification based on } \\
\text { DNA barcode (in Fig. } 5 \text { ) }\end{array}$ & $\begin{array}{c}\text { BOLD } \\
\text { sample ID }\end{array}$ \\
\hline AN27 & Anthrenus dorsatus & ND & $86.83^{*}$ & Anthrenus dorsatus & Anthrenus dorsatus & GJHAN27 \\
\hline AN32 & Anthrenus dorsatus & ND & $86.25^{\star}$ & Anthrenus dorsatus & Anthrenus dorsatus & GJHAN32 \\
\hline AN33 & Anthrenus dorsatus & ND & $86.91^{*}$ & Anthrenus dorsatus & Anthrenus dorsatus & GJHAN33 \\
\hline AN34 & Anthrenus dorsatus & ND & $86.59^{*}$ & Anthrenus dorsatus & Anthrenus dorsatus & GJHAN34 \\
\hline AN36 & Anthrenus dorsatus & ND & $86.62^{*}$ & Anthrenus dorsatus & Anthrenus dorsatus & GJHAN36 \\
\hline AN9 & Anthrenus pimpinellae isabellinus & $\sigma^{\pi}$ & 86.30 & Anthrenus dorsatus & Anthrenus dorsatus & GJHAN09 \\
\hline AN10 & Anthrenus pimpinellae isabellinus & 우 & 86.26 & Anthrenus dorsatus & Anthrenus dorsatus & GJHAN10 \\
\hline AN11 & Anthrenus pimpinellae isabellinus & $\hat{0}$ & 86.28 & Anthrenus dorsatus & Anthrenus dorsatus & GJHAN11 \\
\hline AN12 & Anthrenus pimpinellae isabellinus & 0 & 86.21 & Anthrenus dorsatus & Anthrenus dorsatus & GJHAN12 \\
\hline AN22 & Anthrenus pimpinellae isabellinus & 0 & 86.43 & Anthrenus dorsatus & Anthrenus dorsatus & GJHAN22 \\
\hline AN28 & Anthrenus pimpinellae isabellinus & ND & 86.45 & Anthrenus dorsatus & Anthrenus dorsatus & GJHAN28 \\
\hline AN29 & Anthrenus pimpinellae isabellinus & ND & 86.47 & Anthrenus dorsatus & Anthrenus dorsatus & GJHAN29 \\
\hline AN14 & Anthrenus pimpinellae pimpinellae & 0 & 99.84 & Anthrenus $p$. pimpinellae & Anthrenus p. pimpinellae & GJHAN14 \\
\hline AN15 & Anthrenus pimpinellae pimpinellae & 우 & 99.84 & Anthrenus $p$. pimpinellae & Anthrenus $p$. pimpinellae & GJHAN15 \\
\hline AN16 & Anthrenus pimpinellae pimpinellae & 후 & 100 & Anthrenus $p$. pimpinellae & Anthrenus p. pimpinellae & GJHAN16 \\
\hline AN18 & Anthrenus pimpinellae pimpinellae & 우 & 99.53 & Anthrenus $p$. pimpinellae & Anthrenus p. pimpinellae & GJHAN18 \\
\hline AN19 & Anthrenus pimpinellae pimpinellae & $\hat{0}$ & 99.84 & Anthrenus $p$. pimpinellae & Anthrenus p. pimpinellae & GJHAN19 \\
\hline AN20 & Anthrenus pimpinellae pimpinellae & $\sigma^{\pi}$ & 99.84 & Anthrenus p. pimpinellae & Anthrenus p. pimpinellae & GJHAN20 \\
\hline AN21 & Anthrenus pimpinellae pimpinellae & 우 & 99.84 & Anthrenus $p$. pimpinellae & Anthrenus p. pimpinellae & GJHAN21 \\
\hline AN23 & Anthrenus pimpinellae pimpinellae & $\hat{0}$ & 99.84 & Anthrenus $p$. pimpinellae & Anthrenus p. pimpinellae & GJHAN23 \\
\hline AN24 & Anthrenus scrophulariae albidus & ND & 98.83 & $\mathrm{n} / \mathrm{a}$ & Anthrenus scrophulariae & GJHAN24 \\
\hline AN25 & Anthrenus scrophulariae albidus & ND & 99.00 & $\mathrm{n} / \mathrm{a}$ & Anthrenus scrophulariae & GJHAN25 \\
\hline AN26 & Anthrenus scrophulariae albidus & ND & 99.17 & $\mathrm{n} / \mathrm{a}$ & Anthrenus scrophulariae & GJHAN26 \\
\hline AN37 & Anthrenus scrophulariae albidus & ND & 98.89 & $\mathrm{n} / \mathrm{a}$ & Anthrenus scrophulariae & GJHAN37 \\
\hline AN38 & Anthrenus scrophulariae albidus & ND & 98.09 & $\mathrm{n} / \mathrm{a}$ & Anthrenus scrophulariae & GJHAN38 \\
\hline
\end{tabular}



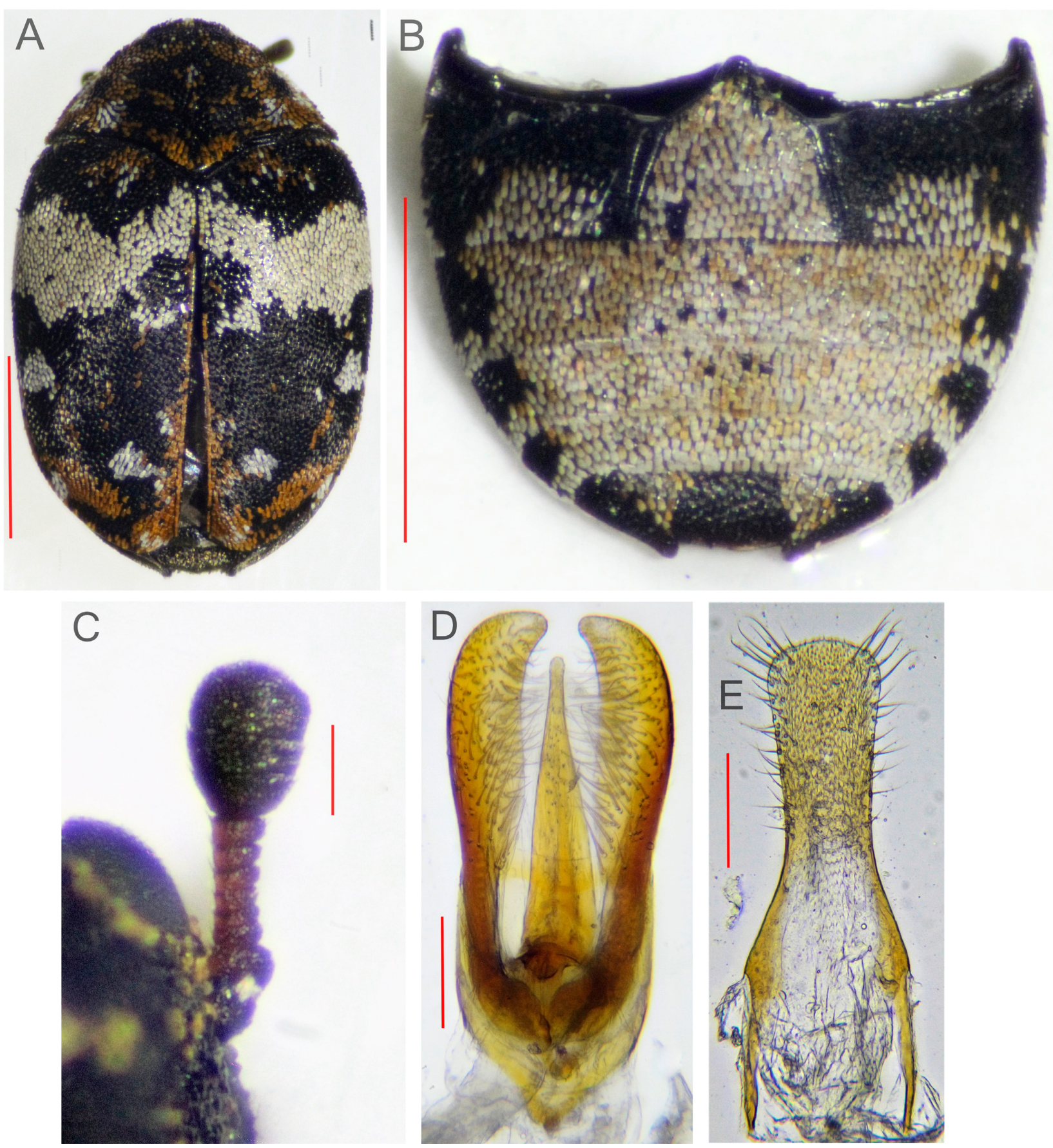

Fig. 1. Anthrenus pimpinellae ssp. pimpinellae, male, typical examples of (a) habitus coloration, (b) ventrites, (c) antenna, (d) aedeagus, and (e) sternite IX. Scale bar $=1 \mathrm{~mm}$ for $1 \mathrm{a}$ and $1 \mathrm{~b}, 100 \mu \mathrm{m}$ for $1 \mathrm{c}, 1 \mathrm{~d}$, and $1 \mathrm{e}$.

\section{Morphological and morphometric analysis}

The following specimens were used in the morphometric analysis: Anthrenus pimpinellae pimpinellae: Greece 9 males (field collected, Thessaloniki), France 1 male (NHM collection); $A n$ threnus pimpinellae isabellinus: Mallorca 2 males (field collected, Pollensa), Greece 1 male (field collected, Thessaloniki), US 1 male (field collected, Maryland), Spain 1 male (NHM collection), 1 male labelled 'Europe' (NHM collection), Algeria 1 male (NHM collection), Morocco 1 male (NHM collection); $A$. dorsatus: Greece 9 males (field collected, Thessaloniki), Mallorca 9 males (field collected, Pollensa), Spain 1 male (NHM collection).

Identification was based on genital and antennal structure, along with habitus body plan and colouration. Dissection involved detaching the abdomen from the rest of the insect using two entomological micropins. The soft tergites were then peeled off the harder ventrites to expose the aedeagus. Sternite IX was also detached from the aedeagus. Images were taken using a Canon EOS 1300D and stacked by Helicon Focus 6-Pro focus stacking software. Habitus images were captured at $\times 20$ magnification and images of the antennae were recorded at $\times 63$ magnification. Images of the genitalia were captured at $\times 100$ magnification using a Brunel monocular SP28 microscope. Morphometric measurements were taken using DsCap.Ink software. Identification was confirmed using Kadej et al. (2007), Holloway et al. (2019) and Holloway \& Bakaloudis $(2019,2020)$. All statistical analyses were carried out using Minitab (version 19) software. To increase stringency in statistical analyses between the same pair of taxa, Bonferroni correction was applied to P values (Rosenthal 



Fig. 2. Anthrenus dorsatus, male, typical examples of (a) habitus coloration, (b) ventrites, (c) antenna, (d) aedeagus, and (e) sternite IX. Scale bar $=1 \mathrm{~mm}$ for $2 \mathrm{a}$ and $2 \mathrm{~b}, 100 \mu \mathrm{m}$ for $2 \mathrm{c}, 2 \mathrm{~d}$, and $2 \mathrm{e}$.

\& Rubin, 1987). Following correction, significance levels $\mathrm{p}<$ $0.05, \mathrm{p}<0.01$, and $\mathrm{p}<0.001$, are indicated as *,**, and ***, respectively. Non-significant results are indicated ns. Means and standard errors are provided.

The following measurements were taken:

1. Body length (BL) (front edge of pronotum to tip of elytra)

2. Body width (BW) (maximum width across the elytra)

3. Paramere length (PL) (from the posterior tip of the paramere to the to the anterior end where the parameres meet)

\section{Genetic analysis}

DNA was extracted using a high salt protocol (Paxton et al., 1996) from 25 adult beetles, bred in captivity from insects col- lected from Sindos, near Thessaloniki (Greece), comprising $A$. dorsatus $(\mathrm{n}=5), A$. $p$. isabellinus $(\mathrm{n}=7)$, A. $p$. pimpinellae $(\mathrm{n}=$ 8 ) and $A$. scrophulariae albidus $(\mathrm{n}=5$; see Table 1$)$. Sequenced individuals comprised a mix of males and females that were determined to species based on colour and morphology (Table 1). Entire insects were crushed for DNA extraction; pinned reference specimens relating to these samples are the parental generation and other F1 offspring of the same breeding vial (G.J. Holloway, private collection). The 25 samples were DNA barcoded at COI, using standard protocols recommended by BOLD (http:// www.barcodinglife.org) with the animal barcode oligonucleotide PCR primers LCO/HCO (Folmer et al., 1994). DNA sequences were used to interrogate NCBI's database using BLAST (https:// 

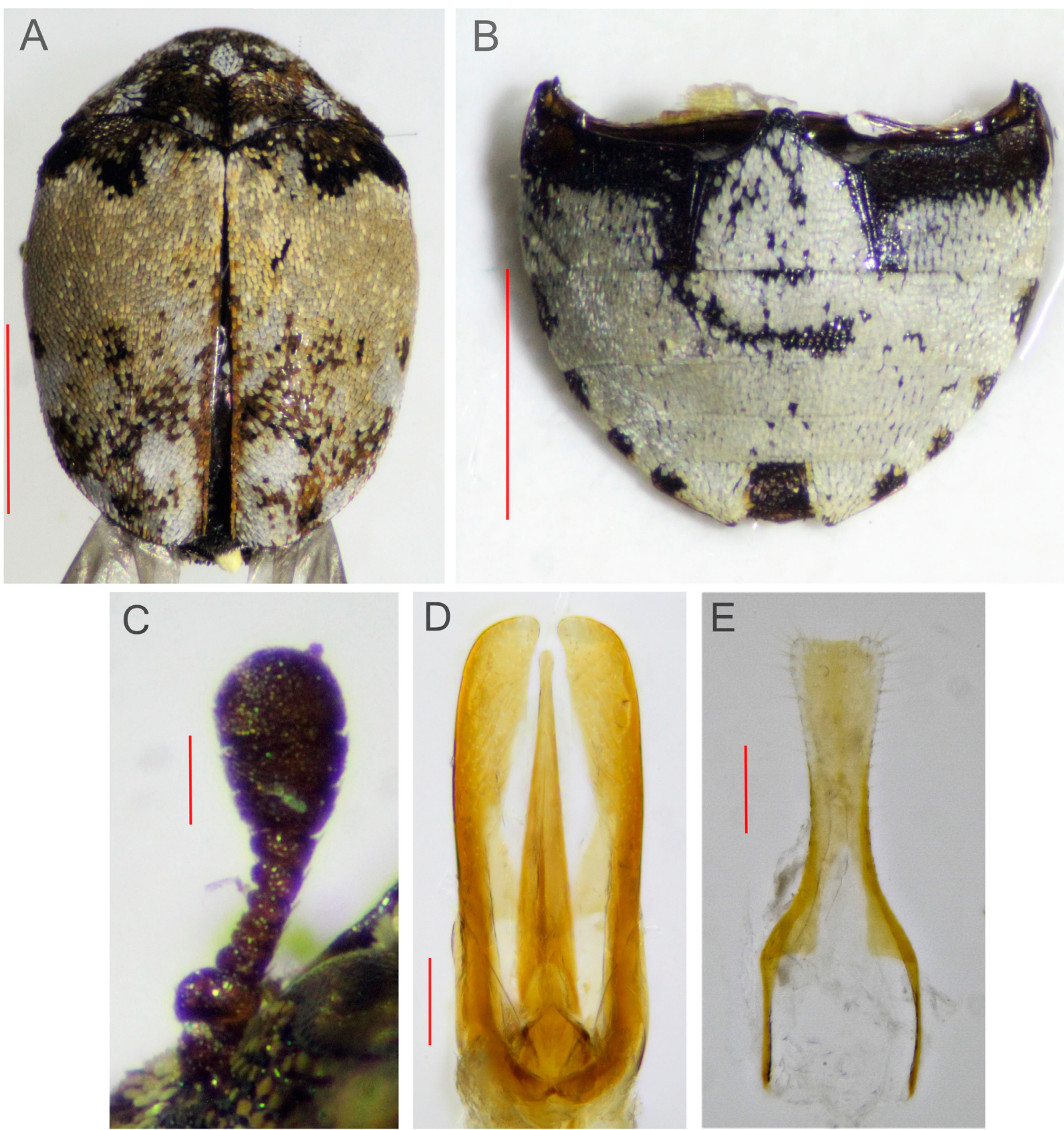

Fig. 3. Anthrenus pimpinellae ssp. isabellinus, male, typical examples of (a) habitus coloration, (b) ventrites, (c) antenna, (d) aedeagus, and (e) sternite IX. Scale bar $=1 \mathrm{~mm}$ for $3 a$ and $3 b, 100 \mu \mathrm{m}$ for $3 c, 3 d$, and $3 e$.

blast.ncbi.nlm.nih.gov/Blast.cgi) and the BOLD COI database (http://www.barcodinglife.org). Beetles bred for sequencing were uniquely numbered (Table 1) and therefore genetic analysis was undertaken blind to species or subspecies identity.

Phylogenetic and evolutionary analyses of the 25 sequences plus 7 additional reference sequences, including conspecifics $[A$. (Anthrenus) festivus Erichson, 1846 from France, A. (A) pimpinellae from Germany, $A$. (A) scrophulariae (Linnaeus, 1758) from Germany, and two species of different subgenera (two sequences each of Anthrenus (Nathrenus) verbasci (Linnaeus, 1767) from Germany and Canada, and Anthrenus (Florilinus) museorum (Linnaeus, 1761) both from Germany], retrieved from the NCBI (GenBank) database, were conducted using MEGA version $\mathrm{X}$ (Kumar et al., 2018; Stecher et al., 2020). Sequences were aligned using ClustalW which, after removal of gaps, revealed a single open reading frame in all sequences of 575 bases (191 amino acids), suggesting sequence quality was good. Substitution model selection by Maximum Likelihood showed the best model based on AICc and BIC to be the TN93+G+I (Tamura-Nei model with a discrete Gamma distribution to model evolutionary rate differences among sites, allowing for some sites to be evolutionarily invariable), which was then employed to generate a phylogenetic tree by Maximum Likelihood, with 500 bootstrap replicates to estimate support for branches. The 25 new sequences generated in this study are publicly available in BOLD (Table 1).

\section{RESULTS}

Figs 1, 2 and 3 show typical examples of A. p. pimpinellae, A. dorsatus and A. p. isabellinus, respectively: (a) habitus, (b) ventrites, (c) antenna, (d) aedeagus, and (e) sternite IX. 


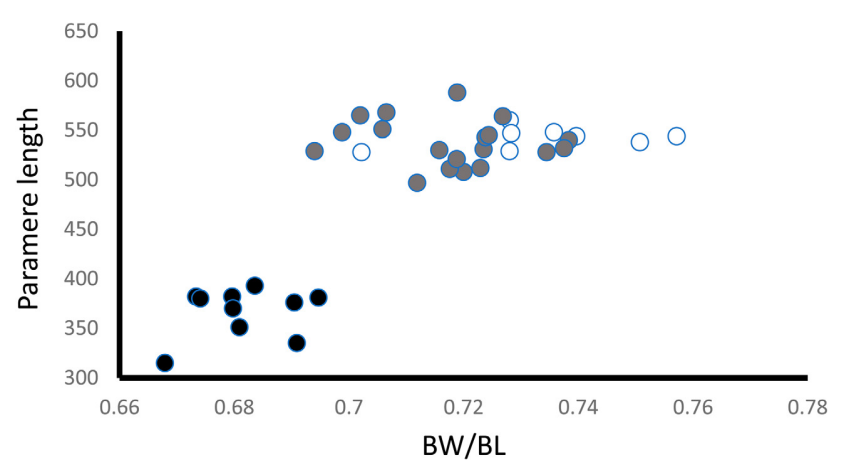

Fig. 4. Paramere length $(\mu \mathrm{m})$ against body width (BW) on body length (BL) for male Anthrenus p. pimpinellae (black), Anthrenus dorsatus (grey), and A. p. isabellinus (open).

The colour patterns of $A$. p. pimpinellae (Fig. 1a) and $A$. dorsatus (Fig. 2a) consist of black, white and orange scales in relatively similar distributions across the elytra. Differences include the width of the trans-elytral white band (narrower in $A$. p . pimpinellae than A. dorsatus), tightness of packing of scales of the white band (spaced apart in $A$. p. pimpinellae, overlapping in $A$. dorsatus), and the finger of white scales joining the posterior edge of the white band to the middle lateral elytral white spot (broken or rudimentary in A. p. pimpinellae, complete in A. dorsatus). The elytral colour pattern of $A$. p. isabellinus (Fig. 3a) is distinctive, and much of the patterns shown in Figs 1a and $2 \mathrm{a}$ are covered in creamy coloured scales, tightly packed at the base of the elytra and becoming more scattered towards the elytral apices.

The ventrites of $A$. p . pimpinellae (Fig. 1b) are off-white as a result of the mixing of white with pale brown scales. At the lateral margins of the sternites are large patches of black scales. The patch on sternite I is very large, meets the lateral margin, and has no white scales on its anterior margin. The ventrites of A. p. isabellinus (Fig. 2b) and A. dorsatus (Fig. $3 b$ ) are very similar in appearance; the bright white scales are closely packed together (in A. p. pimpinellae the scales are more spaced), the patches of black scales along the lateral margins of each sternite are smaller than those of $A$. p pimpinellae, and the patches of black scales on sternite I are sub-lateral, small and surrounded by white scales.

The antennal clubs of $A$. dorsatus (Fig. 2c) and $A$. p. isabellinus (Fig. $3 \mathrm{c}$ ) are similar in shape and show wide sutures between the antennomeres (Kadej et al., 2007). The antennal club of $A$. p. pimpinellae (Fig. 1c) is broader and with narrow sutures between the antennomeres (Kadej et al., 2007).
The aedeagus of A. p. pimpinellae (Fig. 1d) expands from the base to the apex ending in broad, heavily hooked parameres that are covered in shaggy hairs on the dorsal surface. The aedeagi of $A$. dorsatus (Fig. 2d) and A. $p$. pimpinellae (Fig. 3d) are very similar to each other. They are narrower than $A$. $p$. pimpinellae, do not expand much from the base to the apex, are not as broad and hooked as A. p. pimpinellae, and have shorter, sparser hairs on the dorsal surface.

The sternite IX of A. dorsatus (Fig. 2e) and A. p. isabellinus (Fig. 3e) are very similar to each other and show flaps between the anterior horns. Sternite IX of $A$. $p$. pimpinellae (Fig. 1e) does not show these flaps (Kadej et al., 2007).

Table 2 shows the morphometric values for $A$. p. pimpinellae, A. p. isabellinus, and A. dorsatus. For all four of the morphological metrics shown (BL, BW/BL, PL, PL/BL), A. p. isabellinus deviates significantly from $A$. p. pimpinellae. Anthrenus $p$. isabellinus has a longer, rounder body, longer parameres, and longer parameres relative to body length than $A$. p pimpinellae. For all four of these morphological metrics, $A$. p isabellinus does not differ significantly from $A$. dorsatus.

Fig. 4 shows a plot of PL on BW/BL for all specimens of all taxa together. There is an obvious split in the data, with the values for $A$. $p$. pimpinellae occupying a different area within the plot than $A$. dorsatus. The values for the $A$. p. isabellinus specimens nestle comfortably within the $A$. dorsatus data points and are clearly removed from those of A. p. pimpinellae.

\section{Genetic analysis}

All 25 sequences gave high GenBank query coverage $(>97 \%)$ and closest sequence identity $(>85 \%)$ to Anthrenus species (Table 1). The closest BLAST hits in GenBank and the closest BOLD match of $A$. p pimpinellae and $A$. s. scrophulariae were to their respective species, consistently with high sequence identity of $>98 \%$ (Table 1). GenBank and BOLD databases lack reference barcode sequences for A. dorsatus and A. p. isabellinus. Both A. dorsatus and $A$. p. isabellinus had GenBank closest hits to A pimpinellae, but both with a relatively low sequence identity of $<87 \%$ (Table 1). BOLD returned 'no match' for both taxa due to lack of close identity to any reference sequence in the BOLD database. Phylogenetic analysis of our CO1 barcode sequences (Fig. 5) revealed three clear clusters within Anthrenus s. str.: A. p pimpinellae, A. dorsatus plus A. $p$. isabellinus, and $A$. s. scrophulariae, each with high bootstrap support $(100 \%)$. The average sequence variation within the $A$. pimpinellae cluster was $0.07 \%$; within the $A$. dorsatus + A. p. isabellinus cluster it was $0.18 \%$; and with-

Table 2. Morphometrics for Anthrenus $p$. pimpinellae, A. p. isabellinus, and $A$. dorsatus. The units for male body length (BL) are $\mathrm{mm}$ $( \pm S E)$, the units for paramere length $(P L)$ are $\mu \mathrm{m}( \pm \mathrm{SE})$. BW - body width. Statistical comparisons ( $t$ tests plus df) of adjacent pairs of values are provided. ns - not significant, ${ }^{* *} p<0.01,{ }^{* * *} p<0.001$.

\begin{tabular}{|c|c|c|c|c|c|}
\hline & pimpinellae & & isabellinus & & dorsatus \\
\hline $\begin{array}{l}\mathrm{BL} \\
\mathrm{BW} / \mathrm{BL} \\
\mathrm{PL} \\
\mathrm{PL} / \mathrm{BW}\end{array}$ & $\begin{array}{c}2.584 \pm 0.008 \\
0.682 \pm 0.003 \\
366.5 \pm 7.9 \\
0.143 \pm 0.003\end{array}$ & $\begin{array}{l}t_{16}=3.98,{ }^{* *} \\
t_{16}=8.59,{ }^{* * *} \\
t_{16}=18.62,{ }^{* \star *} \\
t_{16}=9.05,{ }^{* * *}\end{array}$ & $\begin{array}{c}3.000 \pm 0.006 \\
0.734 \pm 0.006 \\
542.3 \pm 3.7 \\
0.181 \pm 0.003\end{array}$ & $\begin{array}{l}t_{25}=1.03, \mathrm{~ns} \\
t_{25}=2.39, \mathrm{~ns} \\
t_{25}=0.74, \mathrm{~ns} \\
t_{25}=1.03, \mathrm{~ns}\end{array}$ & $\begin{array}{c}3.101 \pm 0.088 \\
0.718 \pm 0.003 \\
537.4 \pm 5.3 \\
0.174 \pm 0.003\end{array}$ \\
\hline
\end{tabular}




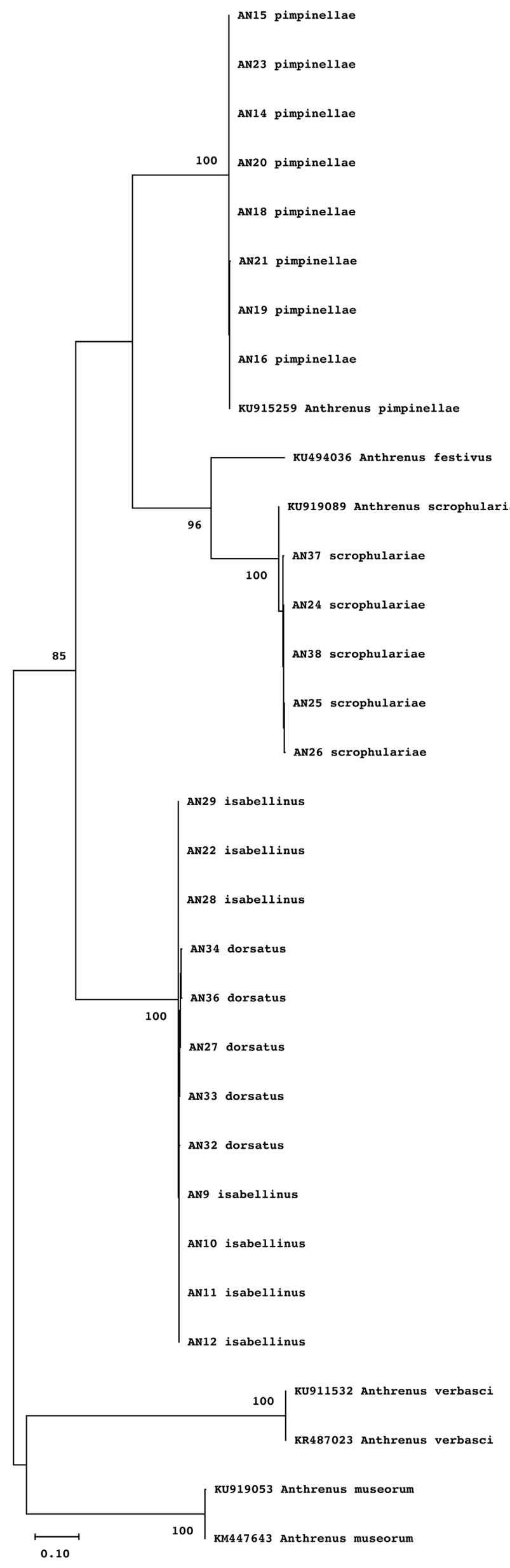

in the $A$. s. scrophulariae cluster it was $0.66 \%$. The average DNA sequence divergence between the $A$. p pimpinellae cluster and the $A$. dorsatus $+A$. $p$. isabellinus cluster was $13.35 \%$. These values of high between-group sequence divergence versus low within-group sequence variation coupled to the well supported phylogeny are strong evidence that the three clusters represent separate species and that $A$. dorsatus and A. p. isabellinus are conspecific.

\section{Distribution}

Fig. 6 shows the known circum-Mediterranean distributions of $A$. p. isabellinus and A. dorsatus. There is extensive overlap between $A$. dorsatus and $A$. $p$. isabellinus.

\section{Taxonomy}

As a result of the data set out above, we hereby restore Anthrenus isabellinus Küster, 1848 to full species status from a subspecies of $A$. pimpinellae and propose the following new synonymy: Anthrenus dorsatus Mulsant \& Rey, 1868 is a junior subjective synonym of Anthrenus isabellinus Küster, 1848.

\section{DISCUSSION}

Here we examined two forms that have been accepted as subspecies for nearly 160 years, but one subspecies ( $A$. $p$. isabellinus) was believed to exist wholly within the spatial distribution of the nominotypical subspecies (A. p. pimpinellae). We found that $A$. $p$. isabellinus specimens from a variety of geographical locations bear little resemblance to A. p. pimpinellae. They are, without question, different species. Küster (1848) originally described $A$. isabellinus as a full species and Beal (1998) speculated that $A$. p. pimpinellae and A. p. isabellinus were different species. This study has demonstrated that both Küster and Beal were correct.

We examined the specimens using three techniques: morphological comparison, morphometrics, and genetic analysis. Gratifyingly, all three approaches arrived at the same conclusion, that $A$. $p$. isabellinus is not closely related to $A$. pimpinellae and resembles $A$. dorsatus in all respects. This finding is significant since not all workers are able to make genetic comparisons, but morphological and morphometric comparisons are more widely available. Genital structure is one of the most important characters used by taxonomists to differentiate among species (Arnqvist, 1998), and we demonstrate here that careful examination of the genitalia is important in Anthrenus species identification. Moreover, morphological and morphometric comparisons can produce results as sound as those based on DNA sequence data.

Beal (1998) suggested that we probably have a poor understanding of the distribution of the nominotypical $A$. $p$.

Fig. 5. Phylogenetic tree of Anthrenus spp. based on COI barcode sequences of 32 Anthrenus species (575 positions in the final dataset) inferred by Maximum Likelihood and Tamura-Nei model of base substitution (Tamura \& Nei, 1993). The tree with the highest log likelihood is shown, and the percentage of trees $(>80 \%)$ in which the associated taxa clustered together is shown next to the branches (500 bootstraps). The tree is drawn to scale, with branch lengths measured in number of substitutions per site (scale bar as $\%)$ and is midpoint rooted. 


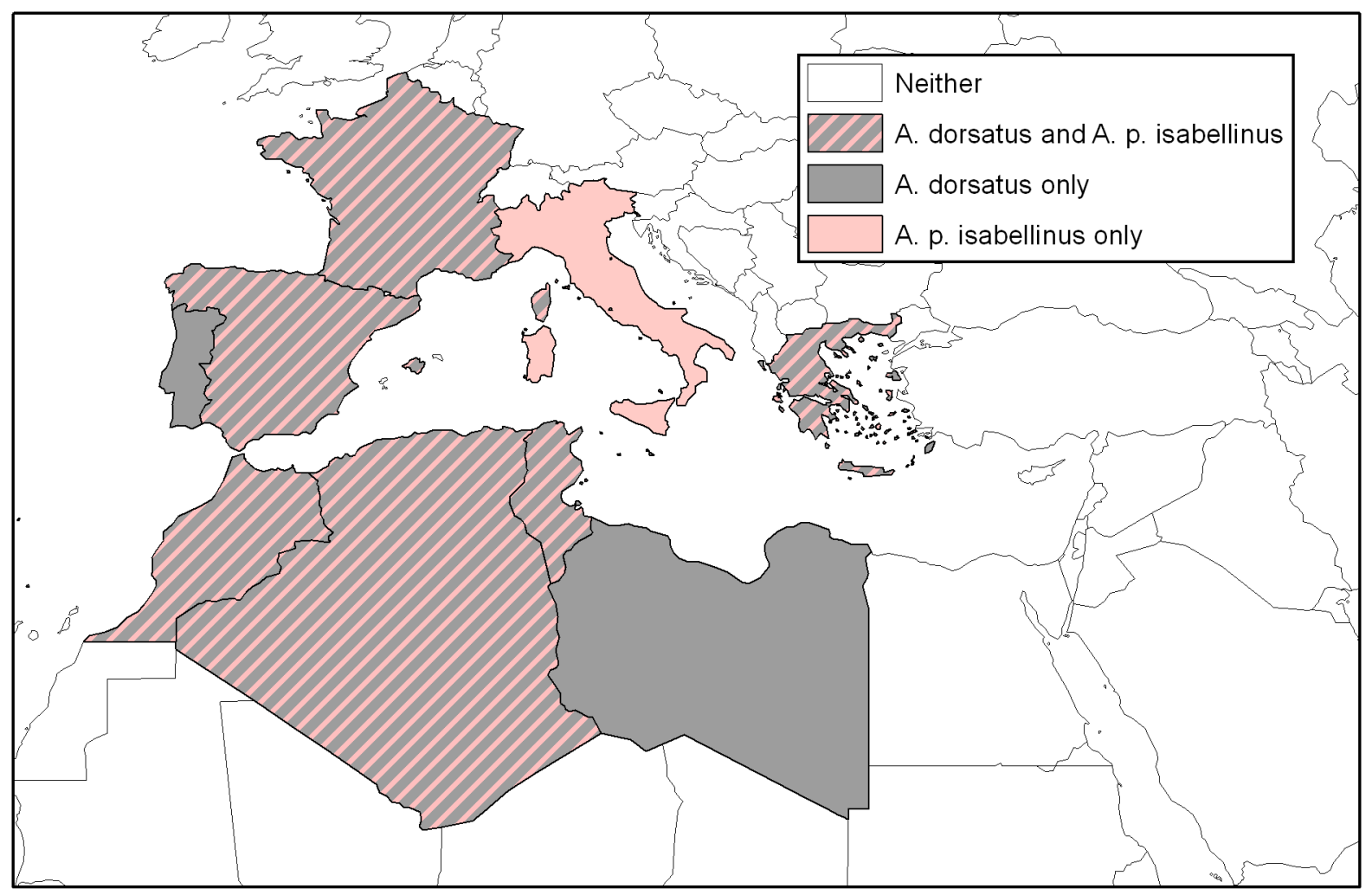

Fig. 6. Overlap between known distributions of $A$. dorsatus and A. p. isabellinus in Europe and North Africa. Data from Háva (2015), Holloway et al. (2019), Holloway \& Bakaloudis (2019) and specimens in the NHM.

pimpinellae due to the degree to which workers confused different species from the A. pimpinellae complex. Anthrenus $p$. pimpinellae is claimed to be almost cosmopolitan. Specimens held in the NHM would suggest that this claim might not be true (G.J. Holloway, pers. obs.). Holloway \& Bakaloudis (2020) showed that there is little intra-specific variation in colour pattern in $A$. $p$. pimpinellae. The current study demonstrated that $A$. $p$. pimpinellae is narrow in shape relative to $A$. isabellinus, with brownish versus clean white ventrites, respectively. These features, body shape and colour pattern, can be quite easily assessed under field conditions. It is hoped that field workers will be able to utilise the information provided here to help to understand the true distribution of $A$. p. pimpinellae.

The majority of $A$. isabellinus both from the field (a sample of over 500 insects from across Europe, GJH unpubl. data) and others reared through in the laboratory have a colour pattern resembling Fig. 2a (80\% of individuals). The remaining $A$. isabellinus possess more whitish elytral scales (20\% of individuals) along a continuous gradient of increasing numbers of paler elytral scales to the palest specimens as shown in Fig. 3a. Furthermore, insects with the colour patterns shown in Fig. 2a produce some offspring resembling Fig. 3a, whilst parental insect resembling Fig. 3 a produce some offspring resembling Fig. $2 \mathrm{a}$. There is no evidence that the different colour patterns are the result of genetic polymorphism. A more parsimonious explanation for the colour pattern gradient is phenotypic plasticity. Colour pattern plasticity is very common across a range of insect taxa. Many Lepidoptera display wing scale colour plasticity in response to developmental period (Holloway et al., 1993; Kemp \& Jones, 2001), with paler wing scales produced by individuals with the shortest developmental periods. In fact, colour pattern plasticity in response to developmental period is common across many insect groups, including Coleoptera (Holloway et al., 1995; Michie et al., 2010), Diptera (Marriott \& Holloway, 1998; Gibert et al., 2007), and Hemiptera (Sorokor et al., 2013; Sibilia et al., 2018). In many cases it has been shown that colour pattern plasticity in insects has adaptive significance (Brakefield \& Reitsma, 1991; Ottenheim et al., 1999; Sibilia et al., 2018). More work is required to establish why and how the variation in colour pattern in A. isabellinus is produced.

ACKNOWLEDGEMENTS. We are very grateful to the Coleoptera curatorial team of the Natural History Museum, London, for providing access to the collections in their care. We are tremendously grateful to two anonymous referees and the editor for making excellent and constructive comments for ways of improving on the original submission.

\section{REFERENCES}

ARNQvist G. 1998: Comparative evidence for the evolution of genitalia by sexual selection. - Nature 393: 784-786.

BEAL R.S. 1998: Taxonomy and biology of Nearctic species of Anthrenus (Coleoptera: Dermestidae). - Trans. Am. Entomol. Soc. 124: 271-332.

BRakefield P.M. \& Reitsma N. 1991: Phenotypic plasticity, seasonal climate and the population biology of Bicyclus butterflies (Satyridae) in Malawi. - Ecol. Entomol. 16: 291-303.

Folmer O., Black M., Hoeh W., Lutz R. \& Vrigenhoek R. 1994: DNA primers for amplification of mitochondrial cytochrome $\mathrm{c}$ 
oxidase subunit I from diverse metazoan invertebrates. - Mol. Marine Biol. Biotechnol. 3: 294-299.

Gibert J.-M., Perronet F. \& Schlötterer C. 2007: Phenotypic plasticity in Drosophila pigmentation caused by temperature sensitivity of a chromatin regulator network. - PLOS Genetics 3(2): e30, $15 \mathrm{pp}$.

Háva J. 2015: World Catalogue of Insects. Vol. 13. Coleoptera Dermestidae. Brill, Leiden, Boston, xxvi $+419 \mathrm{pp}$.

Háva J. 2020: Dermestidae (Insecta: Coleoptera). http://dermestidae.wZ.cz/wp-content/uploads/2020/01/Subfamily-Megatominae.pdf (last accessed 24 Mar. 2020).

Holloway G.J. \& BaKaloudis D.E. 2019: New distributional record of Anthrenus dorsatus Mulsant et Rey, 1868 (Coleoptera, Dermestidae), Thessaloniki, Greece. - Check List 15: 1077-1081.

Holloway G.J. \& BaKaloudis D.E. 2020: A comparative morphological study of Anthrenus pimpinellae pimpinellae (Fabricius, 1775) and Anthrenus amandae Holloway, 2019 (Coleoptera: Dermestidae). - Coleopt. Bull. 74: 315-321.

Holloway G.J., Brakefield P.M. \& Kofman S. 1993: The genetics of wing pattern elements in the polyphenic butterfly, Bicyclus anynana. - Heredity 70: 179-186.

Holloway G.J., Brakefield P.M., De Jong P.W., Ottenheim M.M., De Vos H., Kesbere F. \& Peynenburg L. 1995: A quantitative genetic analysis of an aposematic colour pattern and its ecological implications. - Phil. Trans. Roy. Soc. (B) 348: 373-379.

Holloway G.J., Foster C.W. \& Callaghan A. 2019: New distributional record of Anthrenus dorsatus Mulsant \& Rey, 1868 (Coleoptera, Dermestidae) on the island of Mallorca, Spain. Check List 15: 33-36.

Holloway G.J., BaKaloudis D.E. \& Foster C.W. in press: $A n-$ threnus dorsatus new to the US and a comparison with Anthrenus pimpinellae ssp. pimpinellae (Coleoptera: Dermestidae). - J. Kansas Entomol. Soc. 74(2)[2020].

KADEJ M. 2018: Contribution to Knowledge of the Immature Stages of Dermestidae with Special Emphasis on the Larval Morphology of the Genus Anthrenus Geoffroy, 1762 (Megatominae, Anthrenini). Polish Entomological Monographs No. 16. Polish Entomological Society, Poznań, 180 pp.

Kadej M., Háva J. \& Kalík V. 2007: Review of the Anthrenus pimpinellae species group from Palaearctic region (Coleoptera: Dermestidae: Anthrenini). — Genus 18: 721-750.
KemP D.J. \& Jones R.E. 2001: Phenotypic plasticity in field populations of the tropical butterfly Hypolimnas bolina (L.) (Nymphalidae). - Biol. J. Linn. Soc. 72: 3-5.

Kumar S., Stecher G., Li M., Knyaz C. \& Tamura K. 2018: MEGA X: Molecular evolutionary genetics analysis across computing platforms. - Mol. Biol. Evol. 35: 1547-1549.

Küster H.C. 1848: Die Käfer Europa's. Nach der Natur beschrieben. XIII Heft. Bauer \& Raspe, Nürnberg, 100 pp., 3 pls.

MALLET J. 1995: A species definition for the modern synthesis. Trends Ecol. Evol. 10: 294-299.

Mallet J. 2008: Hybridization, ecological races and the nature of species: empirical evidence for the ease of speciation. - Phil. Trans. Roy. Soc. (B) 363: 2971-2986.

Marriott C.G. \& Holloway G.J. 1998: Colour pattern plasticity in the hoverfly, Episyrphus balteatus: The critical immature stage and reaction norm on developmental temperature. $-J$. Insect Physiol. 44: 113-119.

Ottenheim M.M., Wertheim B., Holloway G.J. \& Brakefield P.M. 1999: Survival of colour-polymorphic Eristalis arbustorum hoverflies in semi-field conditions. - Funct. Ecol. 13: $72-77$.

Paxton R.J., Thorén P.A., Tengö J., Estoup A. \& Pamilo P. 1996: Mating structure and nestmate relatedness in a communal bee, Andrena jacobi (Hymenoptera: Andrenidae), using microsatellites. - Mol. Ecol. 5: 511-519.

Rosenthal R. \& Rubin D.B. 1987: Multiple contrasts and ordered Bonferroni procedures. - J. Educ. Pyschol. 76: 1028-1034.

Schaum H. 1862: Catalogus Coleopterorum Europae. Editio Secunda Aucta et Emendata. Nicolai, Berlin, 130 pp.

Sibilia C.D., Brosko K.A., Hickling C.J., Lily M., Thompson L.M., Grayson K.L. \& Olson J.R. 2018: Thermal physiology and developmental plasticity of pigmentation in the harlequin bug (Hemiptera: Pentatomidae). - J. Insect Sci. 18: 1-8.

Soroker V., Alchanatis V., Harari A., Talebaev S., Anshelevich L., Reneh S. \& Levski S. 2013: Phenotypic plasticity in the pear psyllid, Cacopsylla bidens (Šulc) (Hemiptera, Psylloidea, Psyllidae) in Israel. - Israel J. Entomol. 42: 21-31.

Stecher G., Tamura K. \& Kumar S. 2020: Molecular evolutionary genetics analysis (MEGA) for macOS. - Mol. Biol. Evol. 37: $1237-1239$.

TAmURA K. \& Nei M. 1993: Estimation of the number of nucleotide substitutions in the control region of mitochondrial DNA in humans and chimpanzees. - Mol. Biol. Evol. 10: 512-526.

Received March 25, 2020; revised and accepted November 30, 2020 Published online December 16, 2020 